\title{
原著 $\mathrm{I}$
}

\section{$\mathrm{Si}(\mathrm{Ai})$ 大腸癌の臨床病理学的検討}

井上 雄志鈴木衛手塚徹高崎健 東京女子医科大学消化器病センター外科

過去 10 年間の $\mathrm{Si}(\mathrm{Ai})$ 大腸癌 189 例を臨床病理学的に検討した. $\mathrm{Si}(\mathrm{Ai})$ 大腸癌の占居部 位は盲腸, 下行結腸, 上行結腸と後腹膜に固定されている部位に多かった. 組織学的壁深達度 も si（ai）であったのは 63 例で, 一致率は $35 \%$ \%あった。合併切除部位は腹膜が 64 例と最 も多く, 次いで膀胱が 39 例であり, 臓器別の一致率は胃が 5 例中 4 例 $(80 \%)$, 㓐が 5 例中 3 例 $(60 \%)$ ，結腸が 10 例中 5 例 $(50 \%)$ と高かった. 5 年生存率は根治度 A が $72 \%$ で, 根治 度 B の $13 \%$, 根治度 Cの $0 \%$ に比べ良好であり, 遠隔転移, 腹膜播種などのない症例で検討 しても, se $\left(\mathrm{a}_{2}\right)$ 以浅の根治度 A 症例の 5 年生存率は $75 \%$ で, si (ai) 例の根治度 A 症例の 69 \%と差はなかったが, 根治度 B 例, 根治度 $\mathrm{C}$ 例は $0 \%$ で, 有意に不良であり, $\mathrm{Si}(\mathrm{Ai})$ 大腸 癌の予後向上のためには ew（一）となる積極的な外科切除が重要と思われた.

索引用語 : Si $(\mathrm{Ai})$ 大腸癌

\section{はじめに}

大腸癌は, 腫瘍が限局していることが多いが, 癌腫が進行し, 隣接する組織や臓器に浸潤してい ることはめずらしくはない. 近年の画像診断の進 歩に伴い, 術前に $\mathrm{Si}^{\prime}\left(\mathrm{Ai}^{\prime}\right)$ と診断できる症例は 増加している。 その一方で, 大腸癌, とくに進行 症例では随伴性炎症をきたし, 浸潤が癌性のもの か, 炎症性のものかの判断は, 術前はもち万ん術 中でも困難な場合が少なくない。そこで今回われ われは, 当センターで経験した $\mathrm{Si}(\mathrm{Ai})$ 大腸癌 を臨床病理学的に検討し, $\mathrm{Si}(\mathrm{Ai})$ 大腸癌症例に 遭遇した際の参考に供したい。

\section{I. 対象と方法}

1987 年から 1996 年までの 10 年間に東京女子医 科大学消化器病センターで経験した大腸癌手術例 は 1,443 例である。このうち術中肉眼的に隣接す る組織, あるいは臓器に浸潤ありと判断した 189 例 $(13.1 \%)$ を対象に, 臨床病理学的に検討した。
189 例中 181 例に切除術を行い，180 例 (95.2\%) に合併切除を行った（合併切除を行わなかった 1 例は, 横行結腸癌で十二指腸に癌浸潤を認めたが, H3, P3のため, 腫瘍のみ切除し合併切除は行わ なかった．8例が非切除となり, これらは非切 除の理由を検討した。生存曲線は Kaplan-Meier 法で作成し，一般化Wilcoxon 検定で判定した。 根治度別の累積生存率の検討を行い, 外科的手術 の予後に対する効果を検討するため, 同時期に経 験した組織学的壁深達度が se（ $\left.\mathrm{a}_{2}\right)$ 以浅の根治度 A 例, si (ai) の根治度 A 例と, 肝転移例, 腹膜播種例および D-number $<$ n-number 症例を 除外した根治度 B 例, 根治度 C 例で比較検討し た。

\section{II. 結 果}

1. 癌占居部位別の $\mathrm{Si}(\mathrm{Ai})$ 大腸癌の頻度と $\mathrm{Si}$ (ai) と判断した浸潤臓器

部位は盲腸が 23 例, 上行結腸が 28 例, 横行結 腸が 15 例, 下行結腸が 18 例, S 状結腸が 53 例, 
表 1 癌占居部位別の合併切除部位

\begin{tabular}{|c|c|c|c|c|c|c|c|c|c|c|c|c|c|c|}
\hline 部位 & \multicolumn{2}{|l|}{$\mathrm{C}$} & \multicolumn{2}{|l|}{ A } & \multicolumn{2}{|l|}{$\mathrm{T}$} & \multicolumn{2}{|c|}{$\mathrm{D}$} & \multicolumn{2}{|l|}{$\mathrm{S}$} & \multicolumn{2}{|c|}{$\mathrm{RsRa}_{\mathrm{s}}$} & \multicolumn{2}{|l|}{$\mathrm{Rb}$} \\
\hline 手術例 & \multicolumn{2}{|l|}{102} & \multicolumn{2}{|l|}{185} & \multicolumn{2}{|l|}{143} & \multicolumn{2}{|c|}{96} & \multicolumn{2}{|c|}{385} & \multicolumn{2}{|c|}{325} & \multicolumn{2}{|l|}{207} \\
\hline $\mathrm{Si}(\mathrm{Ai})$ 大腸癌 & \multicolumn{2}{|l|}{$\begin{array}{c}23 \\
(22.5 \%)\end{array}$} & \multicolumn{2}{|c|}{$\begin{array}{c}28 \\
(15.1 \%)\end{array}$} & \multicolumn{2}{|c|}{$\begin{array}{c}15 \\
(10.5 \%)\end{array}$} & \multicolumn{2}{|c|}{$\begin{array}{c}18 \\
(18.8 \%)\end{array}$} & \multicolumn{2}{|c|}{$\begin{array}{c}53 \\
(13.8 \%)\end{array}$} & \multicolumn{2}{|c|}{$\begin{array}{c}33 \\
(10.2 \%)\end{array}$} & \multicolumn{2}{|c|}{$\begin{array}{c}19 \\
(9.2 \%)\end{array}$} \\
\hline 合併切除例 & \multicolumn{2}{|l|}{23} & \multicolumn{2}{|c|}{26} & \multicolumn{2}{|l|}{12} & \multicolumn{2}{|c|}{18} & \multicolumn{2}{|c|}{52} & \multicolumn{2}{|c|}{30} & \multicolumn{2}{|l|}{19} \\
\hline \multirow[t]{9}{*}{ 合併切除部位 } & 腹膜 & 18 & 腹膜 & 19 & 胃 & 5 & 腹膜 & 15 & 膀胱 & 26 & 子宮 & 11 & 膀胱 & 6 \\
\hline & 小腸 & 4 & 十二指腸 & 3 & 大網 & 3 & 脾 & 3 & 腹膜 & 10 & 膀胱 & 7 & 前立腺 & 6 \\
\hline & 結腸 & 2 & 結腸 & 2 & 十二指腸 & 2 & 莝 & 3 & 子宮 & 8 & 尿管 & 7 & 子宮 & 5 \\
\hline & 卵巣 & 1 & 小腸 & 1 & 小腸 & 1 & 小腸 & 1 & 結腸 & 6 & 小腸 & 6 & 胠 & 5 \\
\hline & 十二指腸 & 1 & 腎 & 1 & 肝 & 1 & 結腸 & 1 & 直腸 & 6 & 卵巣 & 5 & 精粪 & 5 \\
\hline & 大網 & 1 & 腸腰筋 & 1 & 脾 & 1 & & & 小腸 & 6 & 精嚢 & 4 & 仙骨 & 2 \\
\hline & & & & & 膵 & 1 & & & 尿管 & 2 & 血管 & 2 & 腹膜 & 2 \\
\hline & & & & & & & & & 卵巣 & 1 & 仙骨 & 1 & 血管 & 1 \\
\hline & & & & & & & & & & & & & 卵巣 & 1 \\
\hline
\end{tabular}

（重複あり）

上部直腸（Rs および $R a ）$ が 33 例，下部直腸 (Rb) が19例であった. Si（Ai）と判断した浸 潤臓器は, 盲腸, 上行結腸は腹膜, 横行結腸は胃, 下行結腸は腹膜, $\mathrm{S}$ 状結腸は膀胱, 上部直腸は子 宮, 下部直腸は膀胱, 前立腺が多かった（表 1 ）.

\section{2. 組織学的壁深達度と合併切除臓器別の癌浸} 潤率

肉眼的に癌浸潤ありと判断して癌腫を切除した 181 例の組織学的壁深達度は $\mathrm{mp}$ が 2 例, ss $\left(\mathrm{a}_{1}\right)$ が 20 例, se $\left(\mathrm{a}_{2}\right)$ が 96 例, si（ai）が 63 例で, 一致率は $34.8 \%$ であった（対象で述べた合併切 除せず癌腫のみ切除した 1 例は seであった). 重 複例を合わせると, のべ 232 力所の浸潤臓器に合 併切除を行い, 71 力所 $(30.6 \%)$ の臟器に癌浸 潤を認めた。合併切除臓器は腹膜が 64 例と最も 多く, 膀胱 39 例, 子宮 25 例, 小腸 19 例などで, 5 例以上の症例で合併切除を行った臓器別の一致 率は, 胃が 5 例中 4 例 $(80 \%)$ と最も高く, 腔が 5 例中 3 例 $(60 \%)$, 結腸が 10 例中 5 例 $(50 \%)$ などであった（表 2$)$.

3. 組織学的判定, ew (十) 例および非切除例

1) 組織学的判定

組織学的判定は切除術を行った 181 例で検討し た。根治度 A は 120 例 $(66.3 \%)$, 根治度 B は 27 例 $(14.9 \%$ ) で, 根治度 B となった理由は, 肝 転移切除が 11 例, 腹膜播種切除が 5 例, ew $(+)$
表 2 合併切除部位別の癌浸潤（5例以上）

\begin{tabular}{ccr}
\hline & 合併切除 & 癌浸潤 $(+)$ \\
\hline 腹膜 & 64 & $14(21.9 \%)$ \\
膀胱 & 39 & $15(38.5 \%)$ \\
子宮 & 25 & $9(36.0 \%)$ \\
小腸 & 19 & $5(26.3 \%)$ \\
結腸 & 10 & $5(50.0 \%)$ \\
尿管 & 9 & $2(22.2 \%)$ \\
精霊 & 9 & $2(22.2 \%)$ \\
卵巣 & 7 & $2(28.6 \%)$ \\
直腸 & 6 & $1(16.7 \%)$ \\
十二指腸 & 6 & $2(33.3 \%)$ \\
前立腺 & 6 & $2(33.3 \%)$ \\
膣 & 5 & $3(60.0 \%)$ \\
胃 & 5 & $4(80.0 \%)$ \\
\hline
\end{tabular}

で肉眼的に遺残なしと判断した症例が 17 例であっ た（重複あり）。根治度 Cは 34 例（18.8％) で, 切除例が 34 例あり, これらの根治度 $\mathrm{C}$ となった 理由は肝転移が 25 例, 腹膜播種が 14 例, リンパ 節転移が 2 例, ew $(+)$ で肉眼的に遺残ありと判 断した症例が 5 例であった（重複あり）（表 $3 ）$.

2) ew $(+)$ 例

ew $(+)$ 例は 22 例あり, 結腸が 4 例, 直腸が 18 例であった。結腸の 4 例はいずれも肝転移あ るいは腹膜播種を伴っている根治度 $\mathrm{C}$ 症例であっ 
た。直腸の 18 例のうち, 肝転移あるいは腹膜播 種を伴っているのは 2 例で, 他の 16 例中 4 例は 骨盤内臓器全摘術（TPE）を行えば, ew (一) が

表 3 組織学的判定 $(n=181)$

\begin{tabular}{|c|c|c|c|}
\hline 根治度 A & \multicolumn{2}{|l|}{$120(66.3 \%)$} & \\
\hline 根治度 B & \multicolumn{2}{|l|}{$27(14.9 \%)$} & \\
\hline & - 肝転移切除 & 11 & \\
\hline & 腹膜転移切除 & 5 & \\
\hline & $\mathrm{ew}(+)$ & 17 & （重複あり） \\
\hline \multirow{6}{*}{$\begin{array}{r}\text { 根治度 C } \\
\text { 絶対非 }\end{array}$} & $34(18.8 \%)$ & & \\
\hline & 台癒切除 & 34 & \\
\hline & -肝転移 & & 25 \\
\hline & 腹膜播種性転移 & & 14 \\
\hline & リンパ節転移 & & 2 \\
\hline & $\mathrm{ew}(+)$ & & 5 （重複あり） \\
\hline
\end{tabular}

得られた可能性があったが, 12 例（うち TPE 4 例）は側方・後方進展で ew（+）であった。

3) 非切除例

非切除は 8 例あり, 直腸が 3 例, 結腸が 5 例で あった。非切除の理由は高度肝転移および腹膜播 種例が多く, 術式は人工肛門造設が 4 例, 消化管 バイパスが 4 例であった（表 4).

\section{4. 遠隔成績}

1) $\mathrm{Si}(\mathrm{Ai})$ 大腸癌の累積 5 年生存率

全体での累積 5 年生存率は $48.9 \%$ であった。 根治度 A の累積生存率は $72.3 \%$ で, 根治度 B の $13.1 \%$ ，根治度 C の $0 \%$ に比べ, 有意に $(\mathrm{p}<0.01)$ 良好であった（図 1$)$.

2）壁深達度, ew 別の累積生存率

根治度 B 例, 根治度 C 例は遠隔転移例, 腹膜

表 4 非切除例 $(\mathrm{n}=8)$

\begin{tabular}{cllll}
\hline & 部位 & \multicolumn{1}{c}{$\mathrm{Si}(\mathrm{Ai})$ 部位 } & \multicolumn{1}{c}{ 非切除の理由 } & \multicolumn{1}{c}{ 術 式 } \\
\hline 1. & $\mathrm{~S}$ & 仙骨, 尿管 & $\mathrm{H} 2, \mathrm{P} 3$ & 人工肛門 \\
2. & $\mathrm{Ra}$ & 仙骨 & 骨盤内に固定 & 人工肛門 \\
3. & $\mathrm{A}$ & 腹膜 & $\mathrm{P} 3$ & 消化管バイパス \\
4. & $\mathrm{A}$ & 後腹膜, 肝, 十二指腸 & $\mathrm{H} 3, \mathrm{P} 3$ & 消化管バイパス \\
5. & $\mathrm{~T}$ & 腹膜 & $\mathrm{H} 3, \mathrm{P} 2$ & 消化管バイパス \\
6. & $\mathrm{Rs}$ & 仙骨 & 骨盤内に固定 & 人工肛門 \\
7. & $\mathrm{~T}$ & 肝, 十二指腸 & 高齢, P1 & 消化管バイパス \\
8. & $\mathrm{Ra}$ & 膀胱, 前立腺 & 高齢, 肺炎併発 & 人工肛門 \\
\hline
\end{tabular}

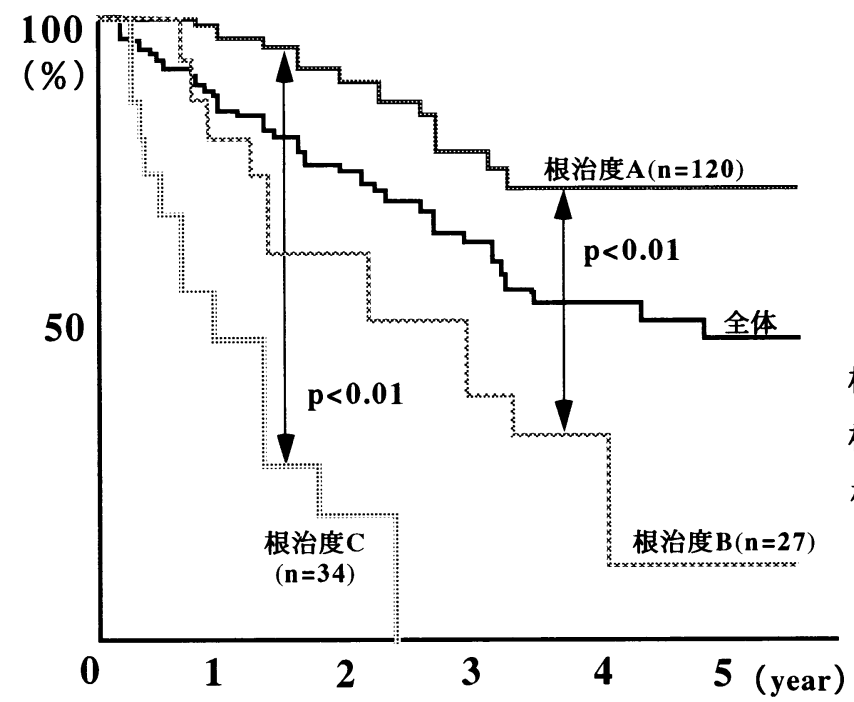

累積5年生存率

全体 $48.9 \%$

根治度A

$72.3 \%$

根治度 B

$13.1 \%$

根治度C

0\%

図 $1 \mathrm{Si}(\mathrm{Ai})$ 大腸癌根治度別累積 5 年生存率 


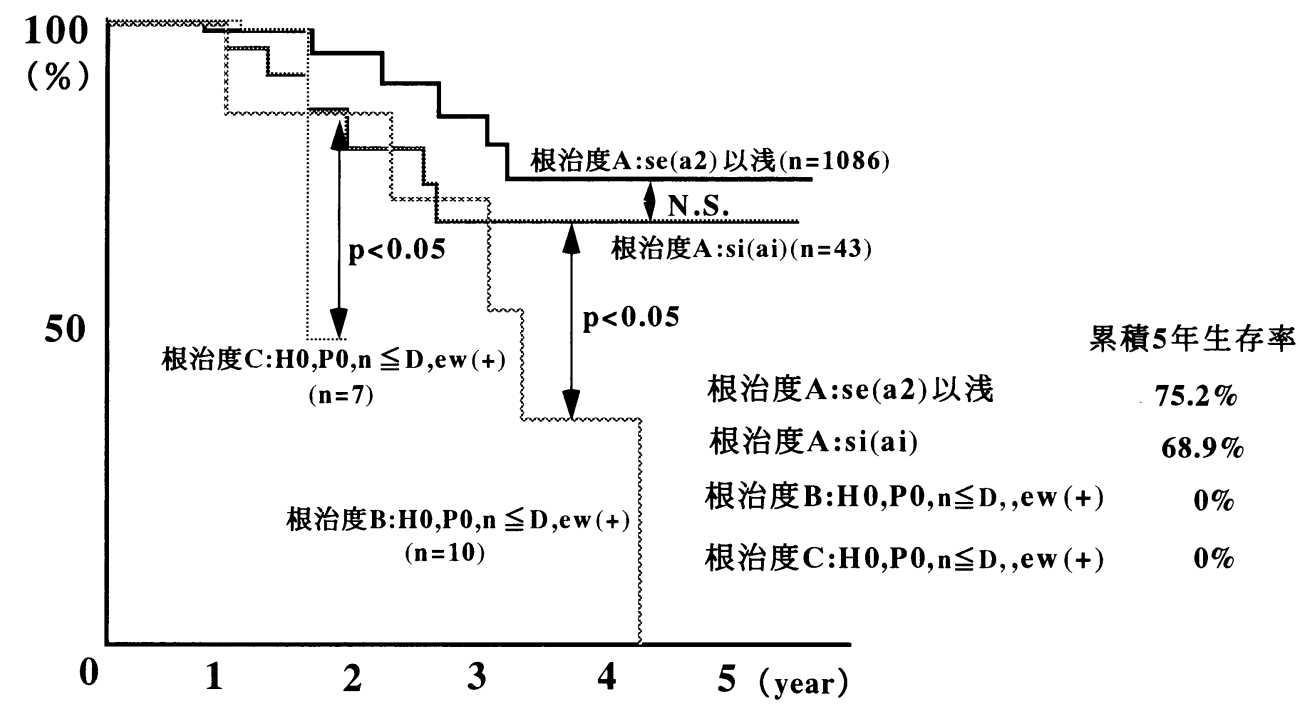

図 2 壁深達度 $\cdot$ ew 別累積 5 年生存率

播種例，D-number $<$ n-number 症例を除いて検討 した. se $\left(\mathrm{a}_{2}\right)$ 以浅の根治度 $\mathrm{A}$ 例の累積 5 年生存 率は $75.2 \%$ で, si (ai) の根治度 A 例の $68.9 \%$ と 差はなかったが, 根治度 $\mathrm{B}$ 例, 根治度 $\mathrm{C}$ 例はそ れぞれ $0 \%$ で，有意に $(\mathrm{p}<0.05)$ 不良であった (図 2).

\section{III. 考察}

大腸癌は他の消化器癌に比べ, 局所の進展傾向 が強く, 隣接臓器へ浸潤を伴う症例が多いとさ $れ^{1)}$, その頻度は $10 \sim 20 \%{ }^{2-4)}$ とされている。し かし大腸癌では周囲に炎症を伴うことが多く，肉 眼的に癌浸潤陽性と判断して, 合併切除を試みて も, 組織学的には癌浸潤を認めないことも多く, また他臓器に浸潤がみられる大腸癌といえども, 遠隔転移, 腹膜播種などの非治癒因子を伴うこと が少なく，積極的な外科切除は予後向上につなが るとされ5), 当センターでも $\mathrm{Si}(\mathrm{Ai})$ 大腸癌 189 例中 180 例 $(95.2 \%)$ と積極的に合併切除を行っ てきた。そこで今回われわれは，当センターで経 験した $\mathrm{Si}(\mathrm{Ai})$ 大腸癌を対象に, 臨床病理学的 に検討を行った。

当センターでの $\mathrm{Si}(\mathrm{Ai})$ 大腸癌の頻度は $13 \%$ であり, 占居部位としては盲腸, 上行結腸, 下行 結腸が多かった。この理由として盲腸から上行結 腸および下行結腸は, 後腹膜により固定されてい
るため可動性に乏しく，比較的容易に他の組織へ 浸潤をおこすためと考えられた。また右側結腸は， 左側結腸に比べ管腔が大きく，便も泥状であるた め, 腫瘍がある程度大きくなるまで, 通過障害に よる症状を起こしにくいことも考えられた。 Si （Ai）となった臓器をみても, 後腹膜により固定 されている盲腸, 上行結腸, 下行結腸は腹膜が最 も多かった。このほかの大腸の $\mathrm{Si}(\mathrm{Ai})$ 臓器で 多いものは, 横行結腸が胃, $S$ 状結腸が膀胱, 上 部直腸（RsRa）が子宮, 下部直腸が膀胱と解剖 学的特徴を反映していた。

$\mathrm{Si}(\mathrm{Ai})$ と判断し, 合併切除した臟器は, のべ 232 力所あり,このうち組織学的にも癌浸潤が認 められたのは約 $30 \%$ \%でた。合併切除部位は 腹膜が最も多く, 膀胱, 子宮の順であり，5例以 上合併した臓器別の一致率をみると, 胃, 腔, 結 腸の順で高かった。今回検討した肉眼的に浸潤陽 性と判断した切除例 181 例の中で組織学的壁深達 度にも si（ai）であったのは約 35\%であり, 半数 以上が se $\left(\mathrm{a}_{2}\right)$ 以浅であった. 肉眼判定と組織学 的診断とが一致しがたいという報告は多く, Goligher ${ }^{6}$ は大腸癌の合併切除例で組織学的にも 癌の他臟器浸潤が認められたのは約 $1 / 3$ に過ぎな いとし, 山口ら ${ }^{5)}$ も $40.7 \%$, 上野ら ${ }^{7)}$ は $40 \%$ と 報告している。しかし合併切除を行い, 組織学的 に壁深達度が se（ $\left.\mathrm{a}_{2}\right)$ 以浅と診断された症例の中 
には標本の切り出しの段階で癌最深部が切れてい ない可能性もあり7), 合併切除が不必要であった と断言はできない.

$\mathrm{Si}(\mathrm{Ai})$ 大腸癌の累積 5 年生存率は, 全体では 約 $50 \%$ であったが, 根治度 A 例は約 $72 \%$ と良 好で, 根治度 B および C 例に比べ有意に良好で あった。また se（ $\mathrm{a}_{2} ）$ 以浅の根治度 $\mathrm{A}$ 例は, si （ai）の根治度 A 例と差はなかったが, 遠隔転移 例, 腹膜播種例, D-number $<$ n-number 症例を除 いた根治度 B 例, 根治度 $\mathrm{C}$ 例で累積 5 年生存率 を検討すると, ew（十）となった症例には根治度 $\mathrm{C}$ はもちろん, 癌は切除し得たと判断された根治 度 B 例にも 5 年生存率はなく, 成績も有意に不良 であった. $\mathrm{Si}(\mathrm{Ai})$ 大腸癌のうち組織学的壁深達 度がsi（ai）であったのは約 $35 \%$ で, 半数以上 がse（ $\mathrm{a}_{2}$ ) 以浅であったことは述べたが, 根治度 $\mathrm{A}$ 例では, se $\left(\mathrm{a}_{2}\right)$ 以浅例と si (ai) 例では生存 率に差はなく, ew $(+)$ 例は有意に不良であった こと, 炎症性の膿瘍の中に癌細胞の浮腫を認めた という報告 ${ }^{8} も$ もることから，積極的な合併切除 が重要であると思われた.

しかし今回の検討でも, 根治度 C となった症例 には 3 年以上の生存例はなく, 山本ら ${ }^{15)}$ も, 根治 度 Cに終わった症例の予後はきわめて不良であり， コントロール不良な遠隔転移巣を有する症例に対 しては, 隣接臓器の合併切除は原則として行うべ きでないとし, $\mathrm{Si}(\mathrm{Ai})$ 大腸癌の予後向上には, ew（一）となるような積極的な外科切除が, とく に遠隔転移，腹膜播種などの非治癒因子を伴わな い症例には重要と思われた。 ew (一) を得る切除 を合併切除部位および術式別に検討してみると， 10 例以上に合併切除を行っていたのは腹膜, 膀 胱, 子宮, 小腸, 結腸で, このうち腹膜, 子宮, 小腸, 結腸は十分に合併切除が可能で, 膀胱は膀 胱三角部に浸潤がない場合は, 骨盤内臓器全摘術 (TPE) の適応はなく, 部分切除で根治切除可能 である。

今回の検討の ew $(+)$ 症例は, 直腸病変が 22 例中 18 例と $80 \%$ 以上を占めており，そのうち 12 例が側方・後方進展で ew（+）であった。狭い 骨盤腔に位置する直腸癌では隣接臓器合併切除し ても ew $(+)$ となる症例も存在する。

合併切除を行う際に術後 quality of life
（QOL）を低下され得る可能性のある術式として, 荤頭十二指腸切除 (PD) と骨盤内藏器全摘術 (TPE) がある。PDの適応となる臓器は, 膵, 十二指腸などがあるが，まず脺浸潤は 4 例あった。 横行結腸の 1 例は H3 であり, 不完全切除となっ たが, 他の 3 例は下行結腸癌で膵尾部切除で根治 可能で, 膵浸潤で PD 施行例はなかった。十二指 腸浸潤は, 十二指腸に広範囲浸潤例でも, 乳頭さ え浸潤を受けていなければ，小腸の augmentationを行えば PD は不要であるとされ ${ }^{9)}$, 十二指 腸浸潤 6 例はいずれも部分切除で切除可能であり， 今回の検討例でも, PD 施行例は横行結腸癌の胃 浸潤症例で 6 番の転移リンパ節が脞頭部に浸潤し ている 1 例のみで, $\mathrm{Si}(\mathrm{Ai})$ 大腸癌の $\mathrm{PD}$ 適応例 は少ないと考えられた。つぎに TPEであるが, TPE は排尿・排便機能の変更および性機能障害 という大きな犠牲を伴う術式であり, Si $(\mathrm{Ai})$ 大 腸癌の一致率が $40 \%$ 以下であることが術式適応 に最も問題となり, 今回検討でも, ew $(+)$ 症例 のうち TPEを行えば ew（一）を得た可能性があっ た症例が 4 例あった。

当センターでは膀胱三角部に癌浸潤を認め, TPE 以外に根治術を行えない症例を適応として いる ${ }^{10)}$.太田ら ${ }^{13)}$ は, 癌が膀胱頸部に浸潤のない 症例は膀胱三角（尿管開口部）が切離線に入って も，回腸の augmentation を行うことで膀胱全摘 は必要なく, QOL を高められるとし, 森 ${ }^{9)} も$ 膀胱 頸部が約 $2 \mathrm{~cm}$ ほど残存し, かつ自律神経が少な くとも片側温存することが可能であれば，小腸を 用いた新膀胱作成術の適応であるとしている. 当 センターでも Si である S 状結腸癌と術後の骨盤 内再発の 2 例に回腸の augmentationによる膀胱 拡張術を行ない, 1 例は自然排尿が可能であり, 根治性を犠牲とせず，比較的良好な術後の QOL を得た ${ }^{14)}$. ew (一) となるならば, 積極的に TPE も適応すべきであるが, 根治性を犠牲としないな らば，治療者側はできるだけ術後の QOL を向上 させるための努力を惜しんではならない。

\section{IV. 結 語}

Si (Ai) 大腸癌 189 例を対象に臨床病理学的に 検討し以下の結果を得た。

1. Si $(\mathrm{Ai})$ 大腸癌は占居部位は盲腸, 上行結 
腸, 下行結腸に多かった。

2. 組織学的壁深達度 si (ai) は 63 例で, 肉 眼的判定 ( $\mathrm{Si}, \mathrm{Ai})$ との一致率は $35 \%$ \%゙あった。 合併切除部位は腹膜が 64 例と最も多く, 膀胱 39 例, 子宮 25 例, 小腸 19 例などで, 臓器別の一致 率は, 胃, 脆, 結腸で高かった。

3. 組織学的判定 $(n=181)$ では, 根治度 $\mathrm{A}$ は 120 例 $(66 \%)$, 根治度 B は 27 例 $(15 \%)$, 根 治度 Cは 34 例（19％）であり，非切除は 8 例で あった。

4. 根治度 A の累積生存率は $72 \%$ で, 根治度 $\mathrm{B}$, 根治度 $\mathrm{C}$ に比べ良好で, se $\left(\mathrm{a}_{2}\right)$ 以浅の根治 度 $\mathrm{A}$ 例の累積 5 年生存率は $75 \%$ で, si（ai）の 根治度 A 例の $69 \%$ と差はなかった。

なお本論文の要旨は, 第 51 回日本消化器外科学会総 会 (東京) で発表した。

\section{文献}

1）小長英二, 後藤精俊, 竹内仁司ほか：結腸癌に扔け る他臓器浸潤症例の検討. 癌の臨 37：959-964, 1991

2) Wood CB, Gillis CR, Hole D, et al: Local tumour invasion as a prognostic factor in colorectal cancer. Br J Surg 68:326-328, 1981
3）富野 充, 粕川俊彦, 堀内義美ほか：大腸癌他臓器 浸潤例の検討. 日消外会誌 $20: 1933-1937,1987$

4) Jensen HE, Balslev I, Nielsen J: Extended surgery in treatment of carcinoma of the colon. Acta Chir Scand 136 : 431-434, 1970

5) 山口明夫, 伊井 徹, 北川裕久ほか：大腸癌隣接臓 器合併切除例の検討. 日臨外医会誌 51:23882392, 1990

6) Goligher JC: Surgery of the Anus, Rectum and Colon. Fourth Cdition. London, Bailliere Tindall, 1980, p 387-389

7）上野雅資, 太田博俊, 畔倉 薰ほか: 結腸合併切除 例の検討。日本大腸肛門病会誌 $43: 1198-1204$, 1990

8) 富田 隆, 田矢功司, 島村栄員ほか：大腸癌他臓器 合併切除例の検討. 日消外会誌 $17: 1574-1578$, 1984

9）森 武生：高度進行大腸癌の治療. 日消外会誌 30 : 1885-1889, 1997

10）井上雄志, 鈴木 衛, 吉田勝俊ほか：si（ai）直腸 癌の臨床病理学的検討. 臨外 $52: 379-382,1997$

11）斎藤典男，更科広実，布村正夫ほか：直腸癌におけ る骨盤内蔵全摘の適応と予後. 日本大腸肛門病会誌 $48: 381-188,1995$

12）福田一郎, 亀山雅雄, 川崎靖仁ほか：直腸癌隣接臓 器合併例の検討。日消外会誌 $20: 1739-1937$, 1987

13）太田博俊，高橋 孝，上野雅資ほか：膀胱浸潤直腸 癌に対する膀胱合併切除, 膀胱再建術 (Ileal cystoplasy）—Googwinの変法による Augmentation一. 日本大腸肛門病会誌 $51: 80-85,1998$

14）鈴木 衛, 井上雄志, 羽生富士夫ほか：膀胱浸潤大 腸癌に対する尿路再建を伴う膀胱拡張術。日臨外医 会誌 58(増刊号) : 511, 1997 


\title{
Analysis of Colorectal Cancer Involving Adjacent Organs
}

\author{
Y. Inoue, M. Suzuki, T. Tezuka and K. Takasaki
}

Department of Surgery, Institute of Gastroenterology,

Tokyo Women's Medical University, Tokyo

One hundred eighty-one patients with colorectal cancer involving adjacent organs ( $\mathrm{Si}, \mathrm{Ai}$ ) were studied clinicopathologically. The incidence of $\mathrm{Si}(\mathrm{Ai})$ colorectal cancer was $23 \%$ in the cecum, $19 \%$ in the descending colon and, $15 \%$ in the ascednding colon. Sixty-three patients (35 \%) were positive for histological invasion of adjacent organs (si, ai). Invasion was predominantly seen in the peritoneum (64 cases) and urinary bladder (39 cases). The incidence of histological invasion was $80 \%$ in the stomach, $60 \%$ in the vagina, and $50 \%$ in the colon. The 5 -year survival rate in curable A lesions was $72 \%$ and significantly higher than in curable B or $\mathrm{C}$ lesions. In patients without liver metastasis, dissemination, and group 4 lymph node metastasis, the 5-year survival rate in patients with no histological invasion to the adjacent organs was $75 \%$, not significantly different from the rate with si (ai) cancer $(69 \%)$, but higher than with histologically positive margins (curable B;0\%, curable $\mathrm{C} ; 0 \%$ ). Therefore, it was important to perform aggressive combined resection for histologically negative margins. 